\title{
Supply Chain Risk Management: A Review of Thirteen Years of Research
}

\section{Célestin Elock Son}

Institut de Développement et de la Prospective (IDP), Université Polytechnique Hauts-de-France, Valenciennes, France

Email: celestin.elockson@uphf.fr

How to cite this paper: Elock Son, C. (2018) Supply Chain Risk Management: A Review of Thirteen Years of Research. American Journal of Industrial and Business Management, 8, 2294-2320. https://doi.org/10.4236/ajibm.2018.812154

Received: October 12, 2018

Accepted: December 7, 2018

Published: December 10, 2018

Copyright (c) 2018 by author and Scientific Research Publishing Inc. This work is licensed under the Creative Commons Attribution International License (CC BY 4.0).

http://creativecommons.org/licenses/by/4.0/

\begin{abstract}
This paper performs a systematic literature review on supply chain risk management (SCRM). This review analyzes 133 articles published between 2005 and the first quarter of 2018. Its main purpose is to identify the developed strategies used to mitigate risks and improve supply chain performance. It appears that there is heterogeneity in the developed strategies and that quantitative methods simulation/modeling are the most used by researchers to mitigate supply chain risks (SCR). Although emphasis is made on the links between SCRM and performance or resilience, risk prevention strategies remain the least represented in the papers analyzed. We also find that there is no superior approach in the set of various risks management strategies and thus it is difficult to linearly establish, the successive evolutions of the models that would replace others.
\end{abstract}

\section{Keywords}

Supply Chain, Risk Management, Performance, Resilience, Mitigation

\section{Introduction}

In its initial form, industrial production was apprehended on a linear diagram modeled on the single flows of products ranging from the supply of raw materials to the manufacturing and then to the market. Today, the short product life cycle combined with uncertain demand makes flow management more complex while lengthening the supply chain. This requires that new constraints must be taken into account in the management system for information, product and financial flows. Some companies have initiated production to order program, others have made upstream and/or downstream integration, and some have relocated or even outsourced to benefit from economies of scale and expertise. All these strategies have not only brought added value to their initiators but also 
generated difficulties in their management. While the objective remains to adapt to a highly changing and demanding environment, the consequences of deployment of each strategy are potential source of risks. These risks related to the loss of control, flexibility, comply with the requirements of quality, costs and deadlines, either the distortion of information due to agents opportunism.

In a context where companies evolve within a vast network of collaborators, the objective of reducing risks can help managers to improve their profitability. For example, just-in-time production to limit waste, use of the Internet or ERP to effectively manage information [1], and the outsourcing of part of its production or transportation activities, are initiatives that have enriched the field of supply chain risk management research [2].

In industrial production chains, this reality is more obvious because the supply of millions of products meets the demand of a great number of people, each with specific preferences in different consumption contexts. While natural disasters, terrorist attacks, personnel strikes, accidents, can cause breaks and lengthen delays [3], above mentioned constraints and fierce competition increase vigilance of the managers.

After the "Subprime" crisis, which revealed the vulnerability of many supply chains, researchers' interest in SCRM issues has increased. And the number of publications available in this field of research experiences a remarkable evolution over the years [2]. Their results are different from one author to another. This testifies to the diversity of approaches around the understanding of the phenomenon. It is this reality that it justifies the choice to conduct a review of the literature on SCRM.

Others literature reviews have addressed the subject before in different angles. For example [4] who investigated about how and why one supply chain disruption would be more severe than another. [3] reviewed various quantitative models for managing supply chain risks. He also related various supply chain risk management (SCRM) strategies with actual practices. More recently, [2] identified and classified potential risks related to different flows. [3] proposed robust strategies for mitigating supply chain disruptions. In the same vein, [5] have developed a conceptual framework of SC robustness that may contribute to increased SC resilience. [6] developed a framework to classify SCRM literature, focusing on risk-reducing and risk-mitigating strategies. The particularity of the present article belongs to the fact that it performs an analysis of the impacts of different risk management strategies identified on SC performance. We therefore aim to answer to the following question: what are the impacts of risks mitigation strategies identified on SC performance?

This article provides a review of the literature of major publications on the period around the subprime crisis and aims to 1) assess the risk considerations and strategies deployed by managers 2) understand the evolution of research on industrial and academic perspectives, 3) identify unexplored areas of the SCRM literature. This research is addressed to researchers and particularly doctorate 
students by providing them with an updated basis of researches on SCRM. It is also to address managers, who will find a set of methods available to help improve their approach to risk management.

This paper is organized around four main activities. As a first step, it presents a review of literature on SCRM. Then, it will make a descriptive analysis of mayor publications identified using a systematic literature review, covering the period of 2005 to 2018. Also, a citation/co-citation analysis is performed. Finally the research presents the different strategies developed by authors to manage Supply Chain risks.

\section{The Literature Review of Supply Chain Risk Management}

\subsection{Risk Definition}

The concept of risk is a confusing multidimensional construct [7]. Its apprehension through several works makes it one of the most discussed issues in management science. Risks can be defined as a possible variation in the distribution of supply chain results, their likelihood and subjective values [8] or a break in flow between the components of the supply chain. [9] defines risk as the probability of a loss and the importance of this loss for the organization or the individual. Risk is usually associated with the negative consequences of this event [10]. The supply chain risks are a set of obstacles to initiatives taken in the context of moving products from their place of production to the final consumer. For [11], risk can be thought of as the probability that an undesirable event will occur at some point in a supply chain and the related consequences of this event on performance of the supply chain. They can therefore be considered as variables of internal or external environmental uncertainties which reduce the predictability of results [12]. These risks are demand-driven and are a result of disruptions emerging from supply chain operations [13]. In fact, these disruptions occur in the physical distribution of products to the end customer, especially in transport operations. Also, demand-related risks can arise from the uncertainty caused by customer's unpredictable orders [14].

Furthermore, the evidence of the risks that arise during the transportation and storage of the goods upstream of the supply chain, as well as the resulting financial losses is indisputable. The loss of goods caused by acts of terrorism, theft and accidents results in an additional cost for suppliers. These include the costs of transportation, the process of replacing goods, and the penalties that suppliers and customers face. As a direct result of these shortcomings, the customers turn to other suppliers to meet their demand and avoid breaks. Indirectly, in case of breakage, the corporate image of supplier can be tarnished.

[15] groups the SCR into four categories and [16] into three. Globally, they can be divided into two broad groups: operational risks and strategic risks [15]. Their treatment may be considered as a means of value creation and a source of competitive differentiation within the supply chain. Above all, it consists of reducing the adverse impact of risk on performance [17]. For [18] there are two 
broad categories of risks affecting supply chain design and management: risks related to supply and demand coordination and disruption risks related to normal business. Table 1 summarizes definitions of supply chain risks.

\subsection{Supply Chain Risk Management (SCRM)}

There is no consensus in the definition of supply chain management (SCM) and SCRM because of their newness in the management science literature. Some authors relate the origin of SCM to the 1990s through the work of [21]. By 1997, [22] identified more than 50 SCM definitions, categorized into five categories. More recently, [23] identified 166 SCM approaches in their attempt to come up with a unique definition.

SCRM is defined as management through coordination or collaboration between channel partners to ensure profitability and continuity [3]. [24] defines SCRM as the firm's ability to understand and manage its economic, environmental and social risks within the supply chain. [17] sees the SCRM as a systematic approach to determining the best course of action in the event of uncertainty, which is by identifying, assessing, understanding, communicating and addressing risk-related issues. The SCRM can also be perceived as a collaborative and coordinated management between the partners in order to ensure profitability to the members of the chain. For [25], the SCRM helps the company build and maintain its competitive advantage. As the importance of managing supply chain risks increases, research in the field focuses on strategic issues [26] [27], and are among those that are making a great progress in this logistics field [28].

[29] argued that SCRM exists as a highly fragmented process involving different actors. [30] defended that there are two ways to manage risk. Firstly, it can be avoided or reduced; secondly it can either be transferred or shared, or accepted as is. From this perspective, risk-taking initiatives require that all stakeholders be integrated in the chain so that the level of understanding is the same for all. In this case, access to a large common database would increase risk acceptance by partners.

For [31], companies adopt two types of strategies in front of crisis: they could first respond in the short run by implementing solutions that allow them to quickly solve the problems. Then they manage their organizations, practices and systems through a learning process that will allow them to adapt more easily to other critical situations. For [32], the SCRM is backed on four key processes include risk identification, risk assessment, risk mitigation and risk monitoring. Earlier, [17] established five phases of risk management: warning signs detection, preparation-prevention, response/reduction, recovery, and learning. [33] proposed 5 stages: risk identification, risk assessment, risk management, risk monitoring, organizational and personal learning including knowledge transfer. Of all these stages, the authors are unanimous on risk identification as preliminary to any process of its management. In this article, we propose a management in six steps drawn as follows (see Figure 1). 
Table 1. supply chain risk definitions.

Authors Type of risks Definitions

[2]

Risks in material, information Risk refers to events with small probability but may occur and financial flows abruptly, and these events bring substantial negative consequences to the system.

Supply risk is defined as the probability of an incident associated with inbound supply from individual supplier

[7] Supply risks failures or the supply market occurring, in which its outcomes result in the inability of the purchasing firm to meet customer demand or cause threats to customer life and safety.

Strategic and operational risks

Probability of a loss and the importance of this loss for the organization or the individual. regulatory, legal and bureaucratic risk; infrastructure; and Risk is the negative deviation from the expected value of a certain performance measure, resulting in undesirable consequences for the focal firm.

catastrophic risk

Risk can be thought of as the probability that an undesirable

[11] Supply risks event will occur during a certain period in a supply chain and the associated consequences of this event that affect the performance of the supply chain.

[13] Supply, demand and Risks can be considered as variables of internal or external environmental uncertainties that reduce the predictability of results.

[19] Operational risks

Risk refers to variations in the distribution of outcomes from expected or agreed targets.

Procedure risks

Control risks

[20] Demand risks

Risk is the variation in the distribution of possible supply Supply risks chain outcomes, their likelihood, and their subjective value. Environmental risks

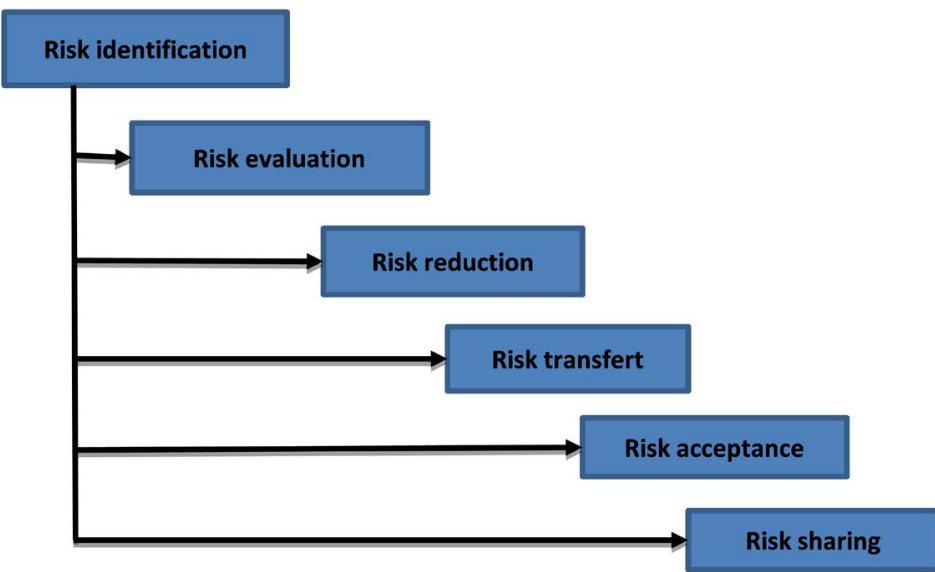

Figure 1. Risk management process.

The identification of potential risks is the first step in crisis management applied to SCM [3] [31] [33] [34]. It is a process of research, recognition and de- 
scription of risk sources, their area(s) of impact, potential events, their causes and their likely consequences.

Risk assessment is a process whose aim is to provide a framework for comparing risks and distinguishing between those that will need to be addressed and those that will not, on the basis of defined criteria. Evaluating risk is to determine its importance or value within the supply chain. Several approaches are used by authors to address this exercise. Among them, simulation techniques that make it possible to evaluate the losses and damages caused by external factors. They are made using advanced mathematical techniques through simulators that produce real-time scenarios of crisis events [35].

The information sharing and trust between supply chain actors considerably reduces risk [36]. The establishment of a transparent information system helps to link physical flows of goods with information flows. This promotes the timely management of transport and handling, and also reduces the risk of misinformation being transmitted [37].

[29] suggested five ways to reduce risk:

- Reducing spatial distance of supply chain partners;

- The establishment of in-house partnership, where the supplier settles in the customer's premises;

- Improvement of the industry knowledge via cooperation and collaboration in buyer-seller relationship;

- Improved product designs in terms of transportability and/or storability that reduces the risk of deterioration;

- Risk spreading based on the implementation of a good level of flexibility or the creation of new options to amortize the risk [38].

Subscription to insurance policies is one of the means of transferring risks. [39] argued that the Insurance Companies could be a driving force to improve the SCRM. In the event of an incident, the insurer partially or fully covers the resulting financial damage. However, the concern stems from the vagueness of the logistics contracts, given the related services that accompany the transportation, handling or warehousing offer regarding the provisions and assurance of the underlying risk evolution [40].

To accept risk is to acknowledge that it as an event to be managed within the company. This acceptance assumes that the company develops comprehensive strategies to cope with risks [41]. This activity is a multi-step process based on the type of risk that managers face. [42] proposed the following risk acceptance steps: planning, mitigation, detection, response, recovery, while [43] proposed four particular stages: apprehension, planning, action and control.

Risk sharing is part of the New Institutional Economy (NEI) logic of [44]. The company feels almost obliged to use outside expertise to build or reinforce the offer for the end customer. Outsourcing is therefore one of the most common risk sharing techniques in the supply chain. Numerous studies have thus measured the link between the outsourcing of secondary activities and performance. Some of these researches analyze the relationship between logistics service pro- 
viders and industrial companies (customers) specifically upstream of the supply chain or throughout the chain. This is the case for example of [45] [46].

From all these developments, we can conclude that the concept of SCRM is at the center of the researchers' concerns. The analysis of the growing number of publications will make it possible to identify the still little explored tracks of this field of research.

\subsection{Research Methodology}

Main databases were investigated since the main objective was to compile all SCRM publications from 2005 to early 2018. The research was first done on Google scholar through keywords such as "supply chain risk", "supply chain risk management", "supply chain uncertainty", "demand risk management”, "supply chain disruption". In a databases such as Emerald Insight, Berkeley Hass, Science Direct (Elsevier), Academy of Management, Scopus, Taylor \& Francis Online, Inform PubOnline, Wiley Online Library, Springer Link, Cairn.info, (EBSCO Host) and ABI/Inform Global (ProQuest). A total of 154 references were identified. We only included the articles published in the journals listed in the HCERES "Economics and Management" 2017. A review of the abstracts and conclusions drawn from various articles made it possible to group them by topic and according to the methodology used by the authors. A descriptive analysis was done to explore the density of the contents treated during this period. We then performed a citation/co-citation analysis to present the most cited papers in the SC research.

\subsection{Result of the Literature Review}

Finally, we selected 132 articles written in English with the exception of [15] in french. We did not consider other languages because the bulk of management science publications are in English. They have been published in 26 journals presented in Table 2.

Three of the 26 journals operated account for $40 \%$ of all identified publications. This includes International Journal of Production Research (26), International Journal of Production Economics (16), and International Journal of Physical Distribution \& Logistics Management (11). About 38\% of these journals appear in the top 20 journals that deals with questions based on SCM in the bibliometrics analysis of [47]. These journals account for $76 \%$ of the publications in this research, with at least 5 publications in the reference period.

Their releases are unequally distributed from one year to the other during the period of reference. Figure 2 shows that the years 2007 (11); 2013 (10); 2008, 2009 and 2012 (12); 2011 and 2015 (15) recorded the most publication on the SCRM. Further, most of them have been published around the 2008 subprime crisis. This reveal the interest of researchers to the subject since the worldwide economics has been affected. Years 2005, 2010 and 2014 have been less productive over the period. 
Table 2. Distribution of articles by review.

\begin{tabular}{|c|c|}
\hline Journal & Number \\
\hline Academy of Management Journal & 1 \\
\hline Business Process Management Journal & 2 \\
\hline California Management Review & 1 \\
\hline Computers \& Industrial Engineering & 3 \\
\hline Decision Sciences & 1 \\
\hline Decision Support Systems & 1 \\
\hline European Journal of Operational Research & 5 \\
\hline Industrial Marketing Management & 1 \\
\hline International Journal of Logistics Research and Applications & 3 \\
\hline International Journal of Operations \& Production Management & 4 \\
\hline International Journal of Physical Distribution \& Logistics Management & 11 \\
\hline International Journal of Production Economics & 16 \\
\hline International Journal of Production Research & 26 \\
\hline Journal of Business Logistics & 5 \\
\hline Journal of Enterprise Information Management & 1 \\
\hline Journal of Manufacturing Technology Management & 2 \\
\hline Journal of Operations Management & 8 \\
\hline Journal of Purchasing \& Supply Management & 3 \\
\hline Journal of the Operational Research Society & 2 \\
\hline Management Science & 2 \\
\hline Omega & 7 \\
\hline Production and Operations Management & 5 \\
\hline Revue française de gestion & 1 \\
\hline Supply Chain Management. An International Journal & 7 \\
\hline The International Journal of Logistics Management & 7 \\
\hline Transportation Research Part E: Logistics and Transportation Review & 7 \\
\hline Total & 132 \\
\hline
\end{tabular}

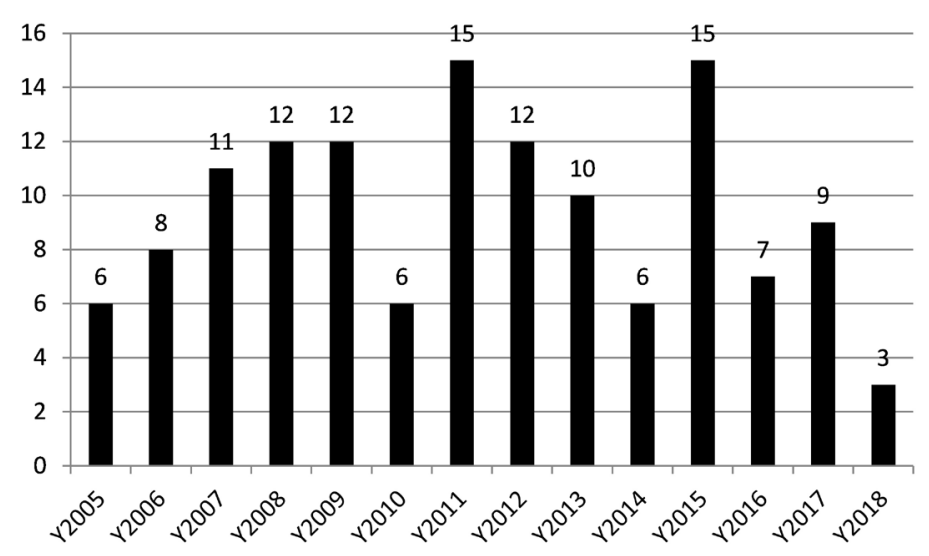

Figure 2. Distribution of SCRM publications over the period of 2005-2018. 
Similarly 8 methods have been identified and presented in Figure 3. As in [6] analysis, simulation and modeling methods dominate followed with survey by questionnaire methods. This result is also close to that of [48] who point out that quantitative, analytical and formal modeling of SCRM research output has been increasing rapidly since 2001. The set of mixed methods is inferior to the conceptual searches found in the database. This result positions the SCRM research more as an engineering related activity than managerial one. Similarly, the number of conceptual researches explains the non-maturation of SCRM research within social science. SCRM research remains in its early stage.

We performed a citation/co-citation analysis to prioritize the articles. [49] suggests that the free quotation service offered by Google Scholar operates a larger count of publications unlike the Web of Science considered to bias the count of articles published in American journals [6]. This research is based on the Google scholar count (performed 02/08/2018) and the following table presents publications with a score of at least 500 citations. $52 \%$ of the exploited items were cited more than 100 times. The most quoted article (1602 times) is that of [18]. By observing Table 3, the number of citations is almost related to the age of the article. In the category of more than 500 citations, only the article of [2] appears among the publications after 2010. In this same category, four articles are conceptual/theoretical analyzes [2] [3] [14] [50], two of which makes use of secondary data [18] [51], a case study [51], two surveys [10] [52] and three publications are simulation/modeling [53] [54] [55], a qualitative analysis [34].

\section{The Main Topics Developed}

\subsection{Risk Sources and Identification}

Risk identification is the first step in order to assure their management as mentioned above. Their care can be preceded by the identification of the sources that led to their occurrence. The identified research addresses this phase in four different ways.

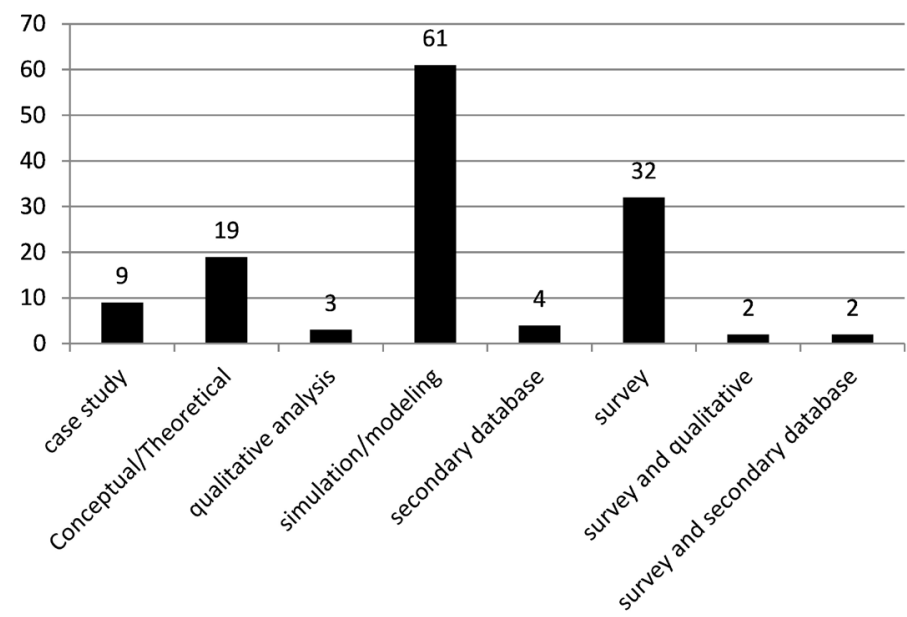

Figure 3. Methodology used. 
Table 3. Papers ranking with citations greater than or equal to 500 .

\begin{tabular}{|c|c|c|c|c|}
\hline Authors & Year & Journal & Title & Citation \\
\hline [18] & 2005 & $\begin{array}{l}\text { Production and } \\
\text { Operations Management }\end{array}$ & $\begin{array}{l}\text { Managing Disruption Risks in Supply } \\
t \text { Chains }\end{array}$ & 1602 \\
\hline [54] & 2006 & Management Science & $\begin{array}{l}\text { On the value of Mitigation and Contingency } \\
\text { Strategies for Managing Supply Chain } \\
\text { Disruption Risks }\end{array}$ & 1203 \\
\hline [4] & $2006 a$ & $\begin{array}{l}\text { International Journal of } \\
\text { Production Economics }\end{array}$ & $\begin{array}{l}\text { Perspectives in Supply Chain Risk } \\
\text { Management }\end{array}$ & 1135 \\
\hline [51] & 2005 & $\begin{array}{l}\text { Production and } \\
\text { Operations } \\
\text { Management }\end{array}$ & $\begin{array}{l}\text { An Empirical Analysis of the Effect of } \\
\text { Supply Chain Disruptions on Long-Run } \\
\text { Stock Price Performance and Equity Risk of } \\
\text { the Firm }\end{array}$ & 970 \\
\hline [3] & 2007 & Decision Sciences & $\begin{array}{l}\text { The Severity of Supply Chain Disruptions: } \\
\text { Design Characteristics and Mitigation } \\
\text { Capabilities }\end{array}$ & 919 \\
\hline [50] & 2006 & $\begin{array}{l}\text { International Journal of } \\
\text { Logistics Research and } \\
\text { Applications }\end{array}$ & $\begin{array}{l}\text { Robust strategies for mitigating supply chain } \\
\text { disruptions }\end{array}$ & 848 \\
\hline [34] & $2008 b$ & $\begin{array}{l}\text { International Journal of } \\
\text { Physical Distribution \& } \\
\text { Logistics Management }\end{array}$ & $\begin{array}{l}\text { Global Supply Chain Risk Management } \\
\text { Strategies }\end{array}$ & 825 \\
\hline [13] & 2005 & $\begin{array}{l}\text { The International } \\
\text { Journal of Logistics } \\
\text { Management }\end{array}$ & $\begin{array}{l}\text { Supply Chain Risk Management: } \\
\text { Understanding the Business Requirements } \\
\text { from a Practitioner Perspective }\end{array}$ & 821 \\
\hline [52] & 2009 & $\begin{array}{l}\text { Journal of Operations } \\
\text { Management }\end{array}$ & $\begin{array}{l}\text { The Organizational Antecedents of a Firm's } \\
\text { Supply Chain Agility for Risk Mitigation and } \\
\text { Response }\end{array}$ & 690 \\
\hline [55] & 2008 & $\begin{array}{l}\text { International Journal of } \\
\text { Production Economics }\end{array}$ & $\begin{array}{l}\text { The Power of Flexibility for Mitigating } \\
\text { Supply Chain Risks }\end{array}$ & 648 \\
\hline [2] & 2011 & $\begin{array}{l}\text { International Journal of } \\
\text { Production Economics }\end{array}$ & $\begin{array}{l}\text { Identifying Risk Issues and Research } \\
\text { Advancements in Supply Chain Risk } \\
\text { Management }\end{array}$ & 573 \\
\hline [10] & 2008 & $\begin{array}{l}\text { Journal of Business } \\
\text { Logistics }\end{array}$ & $\begin{array}{l}\text { An Empirical Examination of Supply Chain } \\
\text { Performance along Several Dimensions of } \\
\text { Risk }\end{array}$ & 553 \\
\hline [53] & 2006 & $\begin{array}{l}\text { Business Process } \\
\text { Management Journal }\end{array}$ & $\begin{array}{l}\text { Supply Chain Risk Mitigation: Modeling the } \\
\text { Enablers }\end{array}$ & 529 \\
\hline
\end{tabular}

- The first group identify risks sources, that is the case of [27] [29]. [27] [29] found two sources of risks, internal and external in which they propose two categories of risks, i.e. endogenous and exogenous risks. [56] found the sources of risks in design where. They thenadvise to consider design as more than a creative function but as a platform for managing risk.

- The second group proposes some categorization of risks within the SC (example of [32] [57] [58]). From their researches, five risks categories are identified: Organizational risk, Environmental risk, Specific risk, Industry risk and Decision maker risk. Other researches of the selected period carried out more or less similar classifications. But the real challenge in this area remains 
the quantification and risk modeling that respects the characteristics of modern supply chains [59].

- The third group proposes meanwhile models that allow the company to select a set of risk agents to be processed and then prioritize the proactive actionsin order to reduce its global impacts to supply chain performance (example of [60]).

- The fourth group of researches proposes a new risk identification methodology for SC based on process engineering (example [60] [61]).

All these means take part in risks identification process even if it remains difficult to accurately identifying points in the SC, where risks can arise [33].

\subsection{Evolution of SCR Management Models}

Authors note several evolution of research on the SCRM. Several strategic changes in the risk management approach have been identified in the field of SC [62]. [63] argued that the 1994 to 2010 publications on the SCRM mobilize different approaches. They note that most of these developments address the subject from a broad perspective, underestimating the relevance of a thorough analysis of the relationship between SCRM strategies and performance. [2] pointed out that "the intellectual structure of the field made statistically significant increased from 2000-2005 and evolved from passively reacting to vague general issues of disruptions towards more proactively managing supply chain risk from system perspectives". For [64], the scientific underpinnings of risk assessment and risk management are still somewhat fragile on some issues.

The evolution of risk apprehension and management models is generally belonging to a debate between quantitative and qualitative analysis approaches that emerge from the different papers [65]. But this debate is more accentuated by the approaches that aim to apply risk theory to the SCRM. The authors point out, however, that this exercise is still in its early stages and that the SCRM models that have been proposed need to be tested empirically. Quantitative models are still limited in their contribution within SCM. They are suitable for managing certain risks such as operational risks, but not others, such as disturbances [3]. So, few researches use quantitative models, which would explain the lack of consensus in defining SC resilience. Therefore, [66] concluded that it is up to the operations and SC managers to identify what quantitative tools are available for different areas of application.

Although the debate on SCRM approaches is dominated by the duo of quantitative and qualitative models, the fact remains that there are more or less solid approaches within SC literature. For example, [47] established that formal modeling of SCRM research can be classified into eight categories from which they recognize supply uncertainty as a mature domain, and "sustainability risk" as an emerging field. The consideration of these elements is at the origin of the divergence of approaches in the literature. It is therefore difficult to consider one of approach as being superior to the other or to establish in a linear stream the successive evolutions of the models that would replace others. 


\subsection{Risks Mitigation Strategies and Resilience}

Risk management within SCs is an ongoing activity. Although many tools allow today to address them, however, they struggle to eradicate completely. The uncertainty surrounding the environment is a catalyst for their occurrence and there is considerable evidence that companies will experience increasing turbulence in the future [67]. Companies looking for flexibility should therefore review their current risk management models that are made in a context of relative stability. However, the literature identifies a plurality of risk mitigation approaches. This plurality is related to diversity of risks surrounding each level of the supply chain. Though, the SCR assessment comes from the careful examination of impacts and from the consideration of cause-and-effect relationships [68].

Thus, some forty articles in this review analyze the impact of disruptions occurrence on the companies' behavior. This research aims globally to prepare the SC to cope with the unexpected. Some authors identify strategies developed to mitigate disturbances. [53] classified effective risk mitigation enablers in two groups: "enablers having a high driving power and low dependence requiring maximum attention and of strategic importance, while another group consists of those variables which have high dependence and are the resultant actions”.

[50] proposes robust strategies to mitigate disruptions. For the author, Supply Alliance Network strategies, Lead Time Reduction, and Recovery Planning Systems will allow a SC to effectively manage inherent fluctuations, regardless of the occurrence of major disruptions within SC activities. In addition, these same strategies will enable a supply chain to become more resilient to major disruptions. In this same order, [69] proposes the Supply Chain Risk Management Process (SCRMP) as an effective management technique for the risks related to the chain. Similarly, [70] identifies robustness and resilience as two key techniques for managing risk. [6] identifies eight unique categories of strategies developed by the authors to mitigate risks under two main approaches: reactive and proactive. She highlights that the reactive strategy is appropriate to address supply and internal risk, while the proactive should be applied to external risks and demand risks. Finally, [55] demonstrates through five stylized models that a firm does not need to invest in a high degree of flexibility to mitigate supply, process and demand risks; because the benefits are achieved for the most part with low levels of flexibility. From the above, we note that the risks assessment should be considered as an ordinary activity of the manager. An effective risk mitigation strategy should be built on consistent and robust internal processes to prepare the business to be proactive in the face of risk occurrence.

Outsourcing is another mitigation strategy. It allow firm to complete his core competences in order to meet market needs and improve their performance through strategic alliances. By making this choice, the company avoids some investment constraints and mitigates breakages that can arise within the SC. [71], proved that the outsourcing option is capable of covering two types of risks 
(production capacity risk, price fluctuation risk). But not all activities are disposed to outsource. Firm can benefit to focusing on producing complex systems internally and outsourcing simple systems [72]. Knowledge granted from outsourcing can also help to improve supply chain practices. It can be used to find best way to manage risk. Managers can use specifics knowledge internally from their experiences or outside by creating strong partnerships with specialized companies. Even if there exists a diverging opinions on the contribution of outsourcing to the SC performance improvement, the benefits of this strategy is recognized by managers. Some researchers found a negative impact of outsourcing on SC performance while others do not. The authors fear that outsourcing reduces the capacity for innovation within the company, reduces flexibility or leads to the loss of control of outsourced activities by managers. The outsourcing strategy must therefore take into account these additional risks. Even if, it is obvious that the problem is not the ignorance of above risks by the managers, the difficulties are inherent in their management [73].

Some authors advocate a careful inventory control to mitigate risks in a financial crisis [74] [75]. This strategy is different from that initiated in ordinary disruptions. For example [76] found that without financial constraints, the supplier always prefers the method of recording, by bearing all the risks on the inventory. In the presence of financial constraints, the supplier will sell part of its stock to pre-ordering retailer, which leads to the sharing of inventory risk in the supply chain. However, [54] shows that inventory control is not an attractive strategy in an environment where disturbances are rare as large quantities of stocks have to be transported for long periods of time without interruption.

The largest number of the above risk management models comes from simulation/modeling methods. Therefore, risk mitigation strategies are not the same from one model to another or from one firm/sector to another. Even if [77] finds that owners of small manufacturing firms adopt the same defensive strategies to supply risks.

\subsection{Risks Management and Performance}

About 25 articles analyze the relationship between risk management and performance within SCs. This research addresses a variety of risks: supply disruption risk [51] [54] [78]-[84] demand and environmental uncertainty [85] [86] [87], outsourcing risk [88], information distortion [89], sustainability risk [90], Operational risk [90] [91].

The occurrence of risks influences business activity at different levels. For example, the impact of terrorist attacks on inventory levels in SC can increase by $600 \%$ compared to normal operating conditions as a result of increasing the security measures on international borders [82]. Generally, when consequences are harsh, firms do not recover quickly from the negative effects of disruption [51]. This can take additional investment in new strategy to access to a certain level of performance. Managers therefore have to look for new network rela- 
tionship: upstream and downstream. In upstream of the SC, the availability of a provider with specific capabilities and the nature of disruptions are key determinants of the optimal strategy [54]. The choice made in the single or multiple sourcing strategy can define the level of chain resilience. [84] found that multiple sourcing dominates single sourcing for low-impact and high-frequency disruptions, regardless of the level of risk aversion. But, single or dual source supply can be effective depending on the magnitude of the disruption probability [80]. Environmental uncertainty has to be integrated in the decision making process. Practices that sufficiently align the strategy and environmental uncertainty are likely to lead to better SC performance [87].

The complexity of the supply base can increase disruptions frequency and reduce business performance. Especially when there are few alternatives in the choice of supply sources. Therefore, a company's level of commitment to its supplier can determine its degree of risk exposure [78]. Paradoxically, [83] assumes that lack of resources and visibility in supply activities can help to mitigate the effects of disruption risk. However, supplier integration can significantly contribute to this and thus provide a foundation to improve the firm's customer performance [85]. In conclusion, we can assume that the optimal choice of suppliers significantly impacts company's performance level.

Two mains considerations emerge from the impact of outsourcing to performance. The first found a significant impact of outsourcing on logistic performance (example [92] [93]) while the second do not (example [46] [94]). As above mentioned, it depends on when and what to outsource. Under production disruption, outsourcing could positivelyimpacts SC performance [88]. Managers are willing to outsource activities that do not provide a competitive advantage to the firm if managing internally [95] and keep those with distinctive capability, valuable, scarce, both difficult and costly to imitate [96].

The information distortion or bullwhip effect is one of the problems that affect the quality of forecasts and thus demand disruptions. It's characterized by an amplification of demand volatility in upstream of the supply chain [10]. It also seems to play an important role in the implementation of decision coordination mechanisms [97]. The authors stress that there is no only one best way to counter with this risk. It's the combination of strategies such as information sharing of sell-through and inventory status data, coordination of orders across retailers and simplification of the pricing/promotional activities of the manufacturer, that help to mitigate bullwhip effect and improve SC performance. A blunt collaboration based on the sharing of complete information between partners can lead to better performance [89].

Table 4 summarizes the main topics covered in various articles of this literature review.

\section{Discussions and Conclusions}

This paper aimed to investigate recent developments in SCRM research. Various 
Table 4. Main topics addressed by authors.

\begin{tabular}{|c|c|c|}
\hline Main topics & Number & Authors \\
\hline $\begin{array}{l}\text { Risk Management } \\
\text { and Performance }\end{array}$ & 25 & [10] [19] [27] [29] [51] [54] [78]-[91] [98] [99] [100] [101] [102] \\
\hline Risks Sources & 5 & {$[10][52][98][103]$} \\
\hline $\begin{array}{l}\text { Disruption and } \\
\text { Mitigation Strategies }\end{array}$ & 20 & [3] [53] [55] [74] [100] [104]-[117] \\
\hline $\begin{array}{l}\text { Disruption and } \\
\text { Resilience Strategies }\end{array}$ & 22 & [3] [18] [51] [79] [84] [88] [89] [97] [114] [118]-[125] \\
\hline $\begin{array}{l}\text { Outsourcing Risk } \\
\text { Management } \\
\text { Strategies }\end{array}$ & 8 & [71] [72] [88] [126] [127] [128] [129] \\
\hline $\begin{array}{l}\text { Financial Risk } \\
\text { Mitigation }\end{array}$ & 7 & [38] [75] [76] [130] [131] [132] [133] \\
\hline $\begin{array}{l}\text { Inventory Risks } \\
\text { Management }\end{array}$ & 3 & [54] [134] [135] \\
\hline $\begin{array}{l}\text { Catastrophic and } \\
\text { Environmental Risks } \\
\text { Management }\end{array}$ & 4 & [42] [82] [136] [137] \\
\hline $\begin{array}{l}\text { Electronic } \\
\text { Marketplaces Risk } \\
\text { Management }\end{array}$ & 2 & [99] [138] \\
\hline $\begin{array}{l}\text { Uncertainty } \\
\text { Management }\end{array}$ & 10 & [67] [71] [74] [85] [86] [87] [98] [139] [140] [141] \\
\hline $\begin{array}{l}\text { Information Risks } \\
\text { Management }\end{array}$ & 6 & {$[89][125][142][143][144][145]$} \\
\hline SCRM Strategies & 56 & $\begin{array}{l}\text { [2] [3] [6] [11] [13] [15] [25] [26] [34] [43] [51] [57] [60] [61] [65] } \\
\text { [68] [69] [70] [77] [81] [91] [101] [106] [109] [131] [135] [144] } \\
{[146]-[163]}\end{array}$ \\
\hline
\end{tabular}

risks were addressed (supply disruption risk, demand uncertainty, information distortion, Operational risk, sustainability risk, Financial Risk mitigation, Inventory risks management, terrorism, Catastrophic and environmental risks) as well as their consequences (loss of profit, less flexibility, customer dissatisfaction, low performance), but also the strategies developed by the researchers and applied by the managers to face the risks (single or multiple sourcing, outsourcing, supplier integration, inventory, customer relationship, mitigation, resilience, ...). This shows the growing interest of the SCRM within the industry.

However, by comparing the place of each group of risks in SCM, i.e., physical or informational flow related risks, a very little space is granted to the second group. Risk management related to physical flows remains the most treated topic [2]. Likewise, most of exploited papers analyze the risks upstream of the chain, specifically, the relations between the company and its suppliers. Very few are addressed to downstream relationships. The relations between the company and its market are almost ignored by the researchers. The very couple of researches that analyses demand uncertainty do not really seek the origin of their incons- 
tancy. However, in a context where industries operate with fierce competition, these parameters should be further deepening based on risk management analysis. Deep market inside uncertainty due to the consumers' behaviors, retailer's power, market heterogeneity, price inconsistency and product characteristics are further preoccupations that authors need to integrate in their SCRM researches. In addition, they may pay more attention to the information flow risk since their management is performance driver.

The authors paid little attention to the analysis of disasters, environmental risks and terrorist acts. Although the occurrence of the former is rare, the green supply chain movement and its requirements in terms of traceability and environment care should be considered as risk factors for SCs. Similarly, terrorism with their related consequences of new security requirements in international transactions, must increasingly integrate risk analysis models.

It is difficult to consider from several approaches of risks management, one as being superior to the others or to establish in a linear stream, the successive evolutions of the models that would replace others. However, dominant methods in the analyzed papers are quantitative with optimization approach, multivariate analysis, options contracts model, stochastic programming and simulation or surveys. There are few conceptual analyzes and very few case studies. This testifies to the maturity of SCRM concept that was suffering from the proven measures. But, the abundance of optimization approaches makes certain research closer to the engineering sciences than the management sciences. This gap deserves to be filled to widen the spectrum of SCRM apprehension.

There is no consensus in the definition of SCR and SCRM. The authors propose definitions approaches according to the nature of the risk and the context of its occurrence. Although there are several SCRM approaches, there is a unanimous agreement in the final objective of this activity: to make SCs more resilient to the occurrence of risks. Unfortunately, there is little risk prevention model in the research explored. Authors should pay more attention to that.

\section{Conflicts of Interest}

The author declares no conflicts of interest regarding the publication of this paper.

\section{References}

[1] Narayanan, V.G. and Raman, A. (2004) Aligning Incentives in Supply Chains. Harvard Business Review, 82, 94-102.

[2] Tang, O. and Musa, S.N. (2011) Identifying Risk Issues and Research Advancements in Supply Chain Risk Management. International Journal of Production Economics, 133, 25-34. https://doi.org/10.1016/j.ijpe.2010.06.013

[3] Tang, C.S. (2006b) Perspectives in Supply Chain Risk Management. International Journal of Production Economics, 103, 451-488. https://doi.org/10.1016/j.ijpe.2005.12.006

[4] Craighead, C.W., Blackhurst, J., Rungtusanatham, M.J. and Handfield, R.B. (2007) 
The Severity of Supply Chain Disruptions: Design Characteristics and Mitigation Capabilities. Decision Sciences, 38, 131-156. https://doi.org/10.1111/j.1540-5915.2007.00151.x

[5] Durach, C.F., Wieland, A. and Machuca, J.A. (2015) Antecedents and Dimensions of Supply Chain Robustness: A Systematic Literature Review. International Journal of Physical Distribution \& Logistics Management, 45, 118-137. https://doi.org/10.1108/IJPDLM-05-2013-0133

[6] Kilubi, I. (2016) The Strategies of Supply Chain Risk Management-A Synthesis and Classification. International Journal of Logistics Research and Applications, 19, 604-629. https://doi.org/10.1080/13675567.2016.1150440

[7] Zsidisin, G.A. (2003) A Grounded Definition of Supply Risk. Journal of Purchasing and Supply Management, 9, 217-224. https://doi.org/10.1016/j.pursup.2003.07.002

[8] March, J.G. and Shapira, Z. (1987) Managerial Perspectives on Risk and Risk Taking. Management Science, 33, 1404-1418. https://doi.org/10.1287/mnsc.33.11.1404

[9] Lavastre, O. and Spalanzani, A. (2010) Comment gérer les risques liés à la chaîne logistique? Une réponse par les pratiques de SCRM.

[10] Wagner, S.M. and Bode, C. (2008) An Empirical Examination of Supply Chain Performance along Several Dimensions of Risk. Journal of Business Logistics, 29, 307-325. https://doi.org/10.1002/j.2158-1592.2008.tb00081.x

[11] Yu, M.C. and Goh, M. (2014) A Multi-Objective Approach to Supply Chain Visibility and Risk. European Journal of Operational Research, 233, 125-130. https://doi.org/10.1016/j.ejor.2013.08.037

[12] Jüttner, U., Peck, H. and Christopher, M. (2003) Supply Chain Risk Management: Outlining an Agenda for Future Research. International Journal of Logistics. Research and Applications, 6, 197-210. https://doi.org/10.1080/13675560310001627016

[13] Jüttner, U. (2005) Supply Chain Risk Management: Understanding the Business Requirements from a Practitioner Perspective. The International Journal of Logistics Management, 16, 120-141. https://doi.org/10.1108/09574090510617385

[14] Nagurney, A., Cruz, J., Dong, J. and Zhang, D. (2005) Supply Chain Networks, Electronic Commerce, and Supply Side and Demand Side Risk. European Journal of Operational Research, 164, 120-142. https://doi.org/10.1016/j.ejor.2003.11.007

[15] Tapiero, C.S. (2008) Analyse des risques et prise de décision dans la chaîne d'approvisionnement. Revue française de gestion, 34, 163-182. https://doi.org/10.3166/rfg.186.163-182

[16] El Ouardighi, F. (2008) Le supply chain management: Concilier centralisation et indépendance organisationnelle. Revue Française de Gestion, 6, 81-88. https://doi.org/10.3166/rfg.186.81-88

[17] Delesse, C. (2010) Sécurisation de la supply chain: Renseignement et intelligence globale. RIRL 2010 Bordeaux September 30th \& October 1st, 2010.

[18] Kleindorfer, P.R. and Saad, G.H. (2005) Managing Disruption Risks in Supply Chains. Production and Operations Management, 14, 53-68. https://doi.org/10.1111/j.1937-5956.2005.tb00009.x

[19] Cheng, S.K. and Kam, B.H. (2008) A Conceptual Framework for Analysing Risk in Supply Networks. Journal of Enterprise Information Management, 21, 345-360. https://doi.org/10.1108/17410390810888642

[20] Christopher, M. and Peck, H. (2004) Building the Resilient Supply Chain. The International Journal of Logistics Management, 15, 1-14. 
https://doi.org/10.1108/09574090410700275

[21] Christopher, M. (1992) Logistics and Supply Chain Management. Pitman Publishing, London.

[22] Bechtel, C. and Jayaram, J. (1997) Supply Chain Management: A Strategic Perspective. The International Journal of Logistics Management, 8, 15-34. https://doi.org/10.1108/09574099710805565

[23] Stock, J.R. and Boyer, S.L. (2009) Developing a Consensus Definition of Supply Chain Management: A Qualitative Study. International Journal of Physical Distribution \& Logistics Management, 39, 690-711. https://doi.org/10.1108/09600030910996323

[24] Carter, C.R. and Rogers, D.S. (2008) A Framework of Sustainable Supply Chain Management: Moving toward New Theory. International Journal of Physical Distribution \& Logistics Management, 38, 360-387. https://doi.org/10.1108/09600030810882816

[25] Lavastre, O., Gunasekaran, A. and Spalanzani, A. (2014) Effect of Firm Characteristics, Supplier Relationships and Techniques Used on Supply Chain Risk Management (SCRM): An Empirical Investigation on French Industrial Firms. International Journal of Production Research, 52, 3381-3403. https://doi.org/10.1080/00207543.2013.878057

[26] Ganguly, K.K. and Guin, K.K. (2011) Understanding Supply Risk in Supply Chain: A Fuzzy Framework. International Journal of Logistics Systems and Management, 8, 267-283. https://doi.org/10.1504/IJLSM.2011.038987

[27] Ritchie, B. and Brindley, C. (2007) An Emergent Framework for Supply Chain Risk Management and Performance Measurement. Journal of the Operational Research Society, 58, 1398-1411. https://doi.org/10.1057/palgrave.jors.2602412

[28] Wieland, A. and Marcus Wallenburg, C. (2012) Dealing with Supply Chain Risks: Linking Risk Management Practices and Strategies to Performance. International Journal of Physical Distribution \& Logistics Management, 42, 887-905. https://doi.org/10.1108/09600031211281411

[29] Ritchie, B. and Brindley, C. (2007) Supply Chain Risk Management and Performance: A Guiding Framework for Future Development. International Journal of Operations \& Production Management, 27, 303-322. https://doi.org/10.1108/01443570710725563

[30] Sudy, I. and Schramm, H.-J. (2010) Risk Response Measures and Their Application from Transportation to Supply Chain Management. RIRL 2010-Bordeaux September 30th \& October 1st, 2010.

[31] Evrard-Samuel, K., Ruel, S. and Spalanzani, A. (2011) Systèmes d'information et résilience des chaînes logistiques globales: Proposition d'un écosystème informationnel.

[32] Ho, W., Zheng, T., Yildiz, H. and Talluri, S. (2015) Supply Chain Risk Management: A Literature Review. International Journal of Production Research, 53, 5031-5069. https://doi.org/10.1080/00207543.2015.1030467

[33] Rangel, D.A., de Oliveira, T.K. and Leite, M.S.A. (2015) Supply Chain Risk Classification: Discussion and Proposal. International Journal of Production Research, 53, 6868-6887. https://doi.org/10.1080/00207543.2014.910620

[34] Manuj, I. and Mentzer, J.T. (2008) Global Supply Chain Risk Management. Journal of Business Logistics, 29, 133-155. https://doi.org/10.1002/j.2158-1592.2008.tb00072.x

[35] Mattos, M.G. and Vaz de Magalhães, D.J.A. (2010) Brazilian Supply Chain Risk 
Analysis, RIRL-Bordeaux September 30th \& October 1st, 2010.

[36] Spiliotopoulou, E., Donohue, K. and Gürbüz, M.Ç. (2016) Information Reliability in Supply Chains: The Case of Multiple Retailers. Production and Operations Management, 25, 548-567. https://doi.org/10.1111/poms.12418

[37] Stopford, M. (2002) E-Commerce-Implications, Opportunities and Threats for the Shipping Business. International Journal of Transport Management, 1, 55-67. https://doi.org/10.1016/S1471-4051(01)00006-4

[38] Triantis, A.J. (2005) Corporate Risk Management: Real Options and Financial Hedging. In: Frenkel, M., Hommel, U. and Rudolf, M., Eds., Risk Management, Springer, Berlin, Heidelberg, 591-608. https://doi.org/10.1007/3-540-26993-2_30

[39] Norrman, A. and Jansson, U. (2004) Ericsson's Proactive Supply Chain Risk Management Approach after a Serious Sub-Supplier Accident. International Journal of Physical Distribution \& Logistics Management, 34, 434-456. https://doi.org/10.1108/09600030410545463

[40] Weiske, A., Vabitsch, A., Olesen, J.E., Schelde, K., Michel, J., Friedrich, R. and Kaltschmitt, M. (2006) Mitigation of Greenhouse Gasemissions in European Conventional and Organic Dairy Farming. Agriculture, Ecosystems \& Environment, 112, 221-232. https://doi.org/10.1016/j.agee.2005.08.023

[41] Elockson, C. (2017) Le management des risques de la supply chain et la performance des entreprises agro-industrielles. Doctoral Dissertation, Artois.

[42] Knemeyer, A.M., Zinn, W. and Eroglu, C. (2009) Proactive Planning for Catastrophic Events in Supply Chains. Journal of Operations Management, 27, 141-153. https://doi.org/10.1016/j.jom.2008.06.002

[43] Lavastre, O., Gunasekaran, A. and Spalanzani, A. (2008) Supply Chain Risk Management in French Companies. Decision Support Systems, 52, 828-838.

https://doi.org/10.1016/j.dss.2011.11.017

[44] Williamson, O.E. (1981) The Economics of Organization: The Transaction Cost Approach. American Journal of Sociology, 87, 548-577. https://doi.org/10.1086/227496

[45] Dabhilkar, M. and Bengtsson, L. (2008) Invest or Divest? On the Relative Improvement Potential in Outsourcing Manufacturing. Production Planning and Control, 19, 212-228. https://doi.org/10.1080/09537280701830144

[46] Pradabwong, J., Braziotis, C., Tannock, J. and Pawar, K.S. (2017) Business Process Management and Supply Chain Collaboration: Effects on Performance and Competitiveness. Supply Chain Management, 22, 107-121.

https://doi.org/10.1108/SCM-01-2017-0008

[47] Charvet, F.F., Cooper, M.C. and Gardner, J.T. (2008) The Intellectual Structure of Supply Chain Management: A Bibliometric Approach. Journal of Business Logistics, 29, 47-73. https://doi.org/10.1002/j.2158-1592.2008.tb00068.x

[48] Fahimnia, B., Tang, C.S., Davarzani, H. and Sarkis, J. (2015) Quantitative Models for Managing Supply Chain Risks: A Review. European Journal of Operational Research, 247, 1-15. https://doi.org/10.1016/j.ejor.2015.04.034

[49] Franceschet, M. (2010) A Comparison of Bibliometric Indicators for Computer Science Scholars and Journals on Web of Science and Google Scholar. Scientometrics, 83, 243-258. https://doi.org/10.1007/s11192-009-0021-2

[50] Tang, C.S. (2006) Robust Strategies for Mitigating Supply Chain Disruptions. International Journal of Logistics: Research and Applications, 9, 33-45. https://doi.org/10.1080/13675560500405584 
[51] Hendricks, K.B. and Singhal, V.R. (2005) An Empirical Analysis of the Effect of Supply Chain Disruptions on Long-Run Stock Price Performance and Equity Risk of the Firm. Production and Operations management, 14, 35-52. https://doi.org/10.1111/j.1937-5956.2005.tb00008.x

[52] Braunscheidel, M.J. and Suresh, N.C. (2009) The Organizational Antecedents of a Firm's Supply Chain Agility for Risk Mitigation and Response. Journal of Operations Management, 27, 119-140. https://doi.org/10.1016/j.jom.2008.09.006

[53] Nishat Faisal, M., Banwet, D.K. and Shankar, R. (2006) Supply Chain Risk Mitigation: Modeling the Enablers. Business Process Management Journal, 12, 535-552. https://doi.org/10.1108/14637150610678113

[54] Tomlin, B. (2006) On the Value of Mitigation and Contingency Strategies for Managing Supply Chain Disruption Risks. Management Science, 52, 639-657. https://doi.org/10.1287/mnsc.1060.0515

[55] Tang, C. and Tomlin, B. (2008) The Power of Flexibility for Mitigating Supply Chain Risks. International Journal of Production Economics, 116, 12-27. https://doi.org/10.1016/j.ijpe.2008.07.008

[56] Khan, O., Christopher, M. and Burnes, B. (2008) The Impact of Product Design on Supply Chain Risk: A Case Study. International Journal of Physical Distribution \& Logistics Management, 38, 412-432. https://doi.org/10.1108/09600030810882834

[57] Rao, S. and Goldsby, T.J. (2009) Supply Chain Risks: A Review and Typology. The International Journal of Logistics Management, 20, 97-123.

https://doi.org/10.1108/09574090910954864

[58] Oke, A. and Gopalakrishnan, M. (2009) Managing Disruptions in Supply Chains: A Case Study of a Retail Supply Chain. International Journal of Production Economics, 118, 168-174. https://doi.org/10.1016/j.ijpe.2008.08.045

[59] Heckmann, I., Comes, T. and Nickel, S. (2015) A Critical Review on Supply Chain risk-Definition, Measure and Modeling. Omega, 52, 119-132.

https://doi.org/10.1016/j.omega.2014.10.004

[60] Nyoman Pujawan, I. and Geraldin, L.H. (2009) House of Risk: A Model for Proactive Supply Chain Risk Management. Business Process Management Journal, 15, 953-967. https://doi.org/10.1108/14637150911003801

[61] Neiger, D., Rotaru, K. and Churilov, L. (2009) Supply Chain Risk Identification with Value-Focused Process Engineering. Journal of Operations Management, 27, 154-168. https://doi.org/10.1016/j.jom.2007.11.003

[62] Ghadge, A., Dani, S. and Kalawsky, R. (2012) Supply Chain Risk Management: Present and Future Scope. The International Journal of Logistics Management, 23, 313-339. https://doi.org/10.1108/09574091211289200

[63] Colicchia, C. and Strozzi, F. (2012) Supply Chain Risk Management: A New Methodology for a Systematic Literature Review. Supply Chain Management. An International Journal, 17, 403-418. https://doi.org/10.1108/13598541211246558

[64] Aven, T. (2016) Risk Assessment and Risk Management: Review of Recent Advances on Their Foundation. European Journal of Operational Research, 253, 1-13. https://doi.org/10.1016/j.ejor.2015.12.023

[65] Khan, O. and Burnes, B. (2007) Risk and Supply Chain Management: Creating a Research Agenda. The International Journal of Logistics Management, 18, 197-216. https://doi.org/10.1108/09574090710816931

[66] Ivanov, D., Dolgui, A., Sokolov, B. and Ivanova, M. (2017) Literature Review on Disruption Recovery in the Supply Chain. International Journal of Production Re- 
search, 55, 6158-6174. https://doi.org/10.1080/00207543.2017.1330572

[67] Christopher, M. and Holweg, M. (2011) "Supply Chain 2.0": Managing Supply Chains in the Era of Turbulence. International Journal of Physical Distribution \& Logistics Management, 41, 63-82. https://doi.org/10.1108/09600031111101439

[68] Gaudenzi, B. and Borghesi, A. (2006) Managing Risks in the Supply Chain Using the AHP Method. The International Journal of Logistics Management, 17, 114-136. https://doi.org/10.1108/09574090610663464

[69] Tummala, R. and Schoenherr, T. (2011) Assessing and Managing Risks Using the Supply Chain Risk Management Process (SCRMP). Supply Chain Management, 16, 474-483. https://doi.org/10.1108/13598541111171165

[70] Behzadi, G., O’Sullivan, M.J., Olsen, T.L. and Zhang, A. (2017) Agribusiness Supply Chain Risk Management: A Review of Quantitative Decision Models. Omega, 79, 21-42. https://doi.org/10.1016/j.omega.2017.07.005

[71] Cucchiella, F. and Gastaldi, M. (2006) Risk Management in Supply Chain: A Real Option Approach. Journal of Manufacturing Technology Management, 17, 700-720. https://doi.org/10.1108/17410380610678756

[72] Novak, S. and Eppinger, S.D. (2001) Sourcing by Design: Product Complexity and the Supply Chain. Management Science, 47, 189-204. https://doi.org/10.1287/mnsc.47.1.189.10662

[73] Shi, Y. (2007) Today's Solution and Tomorrow's Problem: The Business Process Outsourcing Risk Management Puzzle. California Management Review, 49, 27-44. https://doi.org/10.2307/41166393

[74] Trkman, P. and McCormack, K. (2009) Supply Chain Risk in Turbulent Environments-A Conceptual Model for Managing Supply Chain Network Risk. International Journal of Production Economics, 119, 247-258. https://doi.org/10.1016/j.ijpe.2009.03.002

[75] Blome, C. and Schoenherr, T. (2011) Supply Chain Risk Management in Financial Crises-A Multiple Case-Study Approach. International Journal of Production Economics, 134, 43-57. https://doi.org/10.1016/j.ijpe.2011.01.002

[76] Lai, G., Debo, L.G. and Sycara, K. (2009) Sharing Inventory Risk in Supply Chain: The Implication of Financial Constraint. Omega, 37, 811-825. https://doi.org/10.1016/j.omega.2008.06.003

[77] Ellegaard, C. (2008) Supply Risk Management in a Small Company Perspective. Supply Chain Management, 13, 425-434. https://doi.org/10.1108/13598540810905688

[78] Swink, M. and Zsidisin, G. (2006) On the Benefits and Risks of Focused Commitment to Suppliers. International Journal of Production Research, 44, 4223-4240. https://doi.org/10.1080/00207540600575761

[79] Wilson, M.C. (2007) The Impact of Transportation Disruptions on Supply Chain Performance. Transportation Research Part E: Logistics and Transportation Review, 43, 295-320. https://doi.org/10.1016/j.tre.2005.09.008

[80] Yu, H., Zeng, A.Z. and Zhao, L. (2009) Single or Dual Sourcing: Decision-Making in the Presence of Supply Chain Disruption Risks. Omega, 37, 788-800. https://doi.org/10.1016/j.omega.2008.05.006

[81] Zhao, L., Huo, B., Sun, L. and Zhao, X. (2013) The Impact of Supply Chain Risk on Supply Chain Integration and Company Performance: A Global Investigation. Supply Chain Management: An International Journal, 18, 115-131. https://doi.org/10.1108/13598541311318773 
[82] Bueno-Solano, A. and Cedillo-Campos, M.G. (2014) Dynamic Impact on Global Supply Chains Performance of Disruptions Propagation Produced by Terrorist Acts. Transportation Research Part E: Logistics and Transportation Review, 61, 1-12. https://doi.org/10.1016/j.tre.2013.09.005

[83] Brandon-Jones, E., Squire, B. and Van Rossenberg, Y.G. (2015) The Impact of Supply Base Complexity on Disruptions and Performance: The Moderating Effects of Slack and Visibility. International Journal of Production Research, 53, 6903-6918. https://doi.org/10.1080/00207543.2014.986296

[84] Namdar, J., Li, X., Sawhney, R. and Pradhan, N. (2018) Supply Chain Resilience for Single and Multiple Sourcing in the Presence of Disruption Risks. International Journal of Production Research, 56, 2339-2360. https://doi.org/10.1080/00207543.2017.1370149

[85] Boon-Itt, S. and Wong, C.Y. (2011) The Moderating Effects of Technological and Demand Uncertainties on the Relationship between Supply Chain Integration and Customer Delivery Performance. International Journal of Physical Distribution \& Logistics Management, 41, 253-276. https://doi.org/10.1108/09600031111123787

[86] Cardoso, S.R., Barbosa-Póvoa, A.P., Relvas, S. and Novais, A.Q. (2015) Resilience Metrics in the Assessment of Complex Supply-Chains Performance Operating under Demand Uncertainty. Omega, 56, 53-73. https://doi.org/10.1016/j.omega.2015.03.008

[87] Sun, S.Y., Hsu, M.H. and Hwang, W.J. (2009) The Impact of Alignment between Supply Chain Strategy and Environmental Uncertainty on SCM Performance. Supply Chain Management: An International Journal, 14, 201-212. https://doi.org/10.1108/13598540910954548

[88] Giri, B.C. and Sarker, B.R. (2017) Improving Performance by Coordinating a Supply Chain with Third Party Logistics Outsourcing under Production Disruption. Computers \& Industrial Engineering, 103, 168-177. https://doi.org/10.1016/j.cie.2016.11.022

[89] Yang, T. and Fan, W. (2016) Information Management Strategies and Supply Chain Performance under Demand Disruptions. International Journal of Production Research, 54, 8-27. https://doi.org/10.1080/00207543.2014.991456

[90] Shafiq, A., Johnson, P.F., Klassen, R.D. and Awaysheh, A. (2017) Exploring the Implications of Supply Risk on Sustainability Performance. International Journal of Operations \& Production Management, 37, 1386-1407. https://doi.org/10.1108/IJOPM-01-2016-0029

[91] Tazelaar, F. and Snijders, C. (2013) Operational Risk Assessments by Supply Chain Professionals: Process and Performance. Journal of Operations Management, 31, 37-51. https://doi.org/10.1016/j.jom.2012.11.004

[92] Cai, X., Chen, J., Xiao, Y., Xu, X. and Yu, G. (2013) Fresh-Product Supply Chain Management with Logistics Outsourcing. Omega, 41, 752-765. https://doi.org/10.1016/j.omega.2012.09.004

[93] Kotabe, M., Mol, M.J., Murray, J.Y. and Parente, R. (2012) Outsourcing and Its Implications for Market Success: Negative Curvilinearity, Firm Resources, and Competition. Journal of the Academy of Marketing Science, 40, 329-346. https://doi.org/10.1007/s11747-011-0276-Z

[94] Solakivi, T., Töyli, J., Engblom, J. and Ojala, L. (2011) Logistics Outsourcing and Company Performance of SMEs: Evidence from 223 Firms Operating in Finland. Strategic Outsourcing: An International Journal, 4, 131-151. https://doi.org/10.1108/17538291111147982 
[95] Gilley, K.M. and Rasheed, A. (2000) Making More by Doing Less: An Analysis of Outsourcing and Its Effects on Firm Performance. Journal of Management, 26, 763-790. https://doi.org/10.1177/014920630002600408

[96] Espino-Rodríguez, T.F. and Padrón-Robaina, V. (2006) A Review of Outsourcing from the Resource-Based View of the Firm. International Journal of Management Reviews, 8, 49-70. https://doi.org/10.1111/j.1468-2370.2006.00120.x

[97] Wu, T., Blackhurst, J. and O'Grady, P. (2007) Methodology for Supply Chain Disruption Analysis. International Journal of Production Research, 45, 1665-1682. https://doi.org/10.1080/00207540500362138

[98] Hoffmann, P., Schiele, H. and Krabbendam, K. (2013) Uncertainty, Supply Risk Management and Their Impact on Performance. Journal of Purchasing and Supply Management, 19, 199-211. https://doi.org/10.1016/j.pursup.2013.06.002

[99] Rao, S.S., Truong, D., Senecal, S. and Le, T.T. (2007) How Buyers' Expected Benefits, Perceived Risks, and E-Business Readiness Influence Their E-Marketplace Usage. Industrial Marketing Management, 36, 1035-1045. https://doi.org/10.1016/j.indmarman.2006.08.001

[100] Zsidisin, G.A. and Wagner, S.M. (2010) Do Perceptions Become Reality? The Moderating Role of Supply Chain Resiliency on Disruption Occurrence. Journal of Business Logistics, 31, 1-20. https://doi.org/10.1002/j.2158-1592.2010.tb00140.x

[101] Quang, H.T. and Hara, Y. (2018) Risks and Performance in Supply Chain: The Push Effect. International Journal of Production Research, 56, 1369-1388. https://doi.org/10.1080/00207543.2017.1363429

[102] Bode, C., Wagner, S.M., Petersen, K.J. and Ellram, L.M. (2011) Understanding Responses to Supply Chain Disruptions: Insights from Information Processing and Resource Dependence Perspectives. Academy of Management Journal, 54, 833-856. https://doi.org/10.5465/amj.2011.64870145

[103] Grötsch, V.M., Blome, C. and Schleper, M.C. (2013) Antecedents of Proactive supply Chain Risk Management-A Contingency Theory Perspective. International Journal of Production Research, 51, 2842-2867. https://doi.org/10.1080/00207543.2012.746796

[104] Rajesh, R. and Ravi, V. (2015) Modeling Enablers of Supply Chain Risk Mitigation in Electronic Supply Chains: A Grey-Dematel Approach. Computers \& Industrial Engineering, 87, 126-139. https://doi.org/10.1016/j.cie.2015.04.028

[105] Aqlan, F. and Lam, S.S. (2015) Supply Chain Risk Modelling and Mitigation. International Journal of Production Research, 53, 5640-5656. https://doi.org/10.1080/00207543.2015.1047975

[106] Cruz, J.M. (2013) Mitigating Global Supply Chain Risks through Corporate Social Responsibility. International Journal of Production Research, 51, 3995-4010. https://doi.org/10.1080/00207543.2012.762134

[107] Chen, J., Sohal, A.S. and Prajogo, D.I. (2013) Supply Chain Operational Risk Mitigation: A Collaborative Approach. International Journal of Production Research, 51, 2186-2199. https://doi.org/10.1080/00207543.2012.727490

[108] Daultani, Y., Kumar, S., Vaidya, O.S. and Tiwari, M.K. (2015) A Supply Chain Network Equilibrium Model for Operational and Opportunism Risk Mitigation. International Journal of Production Research, 53, 5685-5715. https://doi.org/10.1080/00207543.2015.1056325

[109] Ambulkar, S., Blackhurst, J.V. and Cantor, D.E. (2016) Supply Chain Risk Mitigation Competency: An Individual-Level Knowledge-Based Perspective. International Journal of Production Research, 54, 1398-1411. 
https://doi.org/10.1080/00207543.2015.1070972

[110] Kirılmaz, O. and Erol, S. (2017) A Proactive Approach to Supply Chain Risk Management: Shifting Orders among Suppliers to Mitigate the Supply Side Risks. Journal of Purchasing and Supply Management, 23, 54-65.

https://doi.org/10.1016/j.pursup.2016.04.002

[111] Kumar, S., Liu, J. and Scutella, J. (2015) The Impact of Supply Chain Disruptions on Stockholder Wealth in India. International Journal of Physical Distribution \& Logistics Management, 45, 938-958. https://doi.org/10.1108/IJPDLM-09-2013-0247

[112] Micheli, G.J., Mogre, R. and Perego, A. (2014) How to Choose Mitigation Measures for Supply Chain Risks. International Journal of Production Research, 52, 117-129. https://doi.org/10.1080/00207543.2013.828170

[113] Rajesh, R., Ravi, V. and Venkata Rao, R. (2015) Selection of Risk Mitigation Strategy in Electronic Supply Chains Using Grey Theory and Digraph-Matrix Approaches. International Journal of Production Research, 53, 238-257. https://doi.org/10.1080/00207543.2014.948579

[114] Speier, C., Whipple, J.M., Closs, D.J. and Voss, M.D. (2011) Global Supply Chain Design Considerations: Mitigating Product Safety and Security Risks. Journal of Operations Management, 29, 721-736. https://doi.org/10.1016/j.jom.2011.06.003

[115] Talluri, S., Kull, T.J., Yildiz, H. and Yoon, J. (2013) Assessing the Efficiency of Risk Mitigation Strategies in Supply Chains. Journal of Business Logistics, 34, 253-269. https://doi.org/10.1111/jbl.12025

[116] Wieland, A. and Marcus Wallenburg, C. (2013) The Influence of Relational Competencies on Supply Chain Resilience: A Relational View. International Journal of Physical Distribution \& Logistics Management, 43, 300-320. https://doi.org/10.1108/IJPDLM-08-2012-0243

[117] Diabat, A., Govindan, K. and Panicker, V.V. (2012) Supply Chain Risk Management and Its Mitigation in a Food Industry. International Journal of Production Research, 50, 3039-3050. https://doi.org/10.1080/00207543.2011.588619

[118] Li, J. and Chan, F.T. (2012) The Impact of Collaborative Transportation Management on Demand Disruption of Manufacturing Supply Chains. International Journal of Production Research, 50, 5635-5650. https://doi.org/10.1080/00207543.2011.651540

[119] Ellis, S.C., Henry, R.M. and Shockley, J. (2010) Buyer Perceptions of Supply Disruption Risk: A Behavioral View and Empirical Assessment. Journal of Operations Management, 28, 34-46. https://doi.org/10.1016/j.jom.2009.07.002

[120] Goh, M., Lim, J.Y. and Meng, F. (2007) A Stochastic Model for Risk Management in Global Supply Chain Networks. European Journal of Operational Research, 182, 164-173. https://doi.org/10.1016/j.ejor.2006.08.028

[121] Ambulkar, S., Blackhurst, J. and Grawe, S. (2015) Firm's Resilience to Supply Chain Disruptions: Scale Development and Empirical Examination. Journal of Operations Management, 33, 111-122. https://doi.org/10.1016/j.jom.2014.11.002

[122] Parajuli, A., Kuzgunkaya, O. and Vidyarthi, N. (2017) Responsive Contingency planning of Capacitated Supply Networks under Disruption Risks. Transportation Research Part E: Logistics and Transportation Review, 102, 13-37. https://doi.org/10.1016/j.tre.2017.03.010

[123] Schmitt, A.J. and Singh, M. (2012) A Quantitative Analysis of Disruption Risk in a Multi-Echelon Supply Chain. International Journal of Production Economics, 139, 22-32. https://doi.org/10.1016/j.ijpe.2012.01.004 
[124] Skipper, J.B. and Hanna, J.B. (2009) Minimizing Supply Chain Disruption Risk through Enhanced Flexibility. International Journal of Physical Distribution \& Logistics Management, 39, 404-427. https://doi.org/10.1108/09600030910973742

[125] Wakolbinger, T. and Cruz, J.M. (2011) Supply Chain Disruption Risk Management through Strategic Information Acquisition and Sharing and Risk-Sharing Contracts. International Journal of Production Research, 49, 4063-4084. https://doi.org/10.1080/00207543.2010.501550

[126] Liu, Z. and Nagurney, A. (2011) Supply Chain Outsourcing under Exchange Rate Risk and Competition. Omega, 39, 539-549. https://doi.org/10.1016/j.omega.2010.11.003

[127] Lockamy III, A. and McCormack, K. (2010) Analysing Risks in Supply Networks to Facilitate Outsourcing Decisions. International Journal of Production Research, 48, 593-611. https://doi.org/10.1080/00207540903175152

[128] Olson, D.L. and Wu, D. (2011) Risk Management Models for Supply Chain: A Scenario Analysis of Outsourcing to China. Supply Chain Management: An International Journal, 16, 401-408. https://doi.org/10.1108/13598541111171110

[129] Tsai, M.C., Liao, C.H. and Han, C.S. (2008) Risk Perception on Logistics Outsourcing of Retail Chains: Model Development and Empirical Verification in Taiwan. Supply Chain Management: An International Journal, 13, 415-424. https://doi.org/10.1108/13598540810905679

[130] Berling, P. and Rosling, K. (2005) The Effects of Financial Risks on Inventory Policy. Management Science, 51, 1804-1815. https://doi.org/10.1287/mnsc.1050.0435

[131] Jüttner, U. and Maklan, S. (2011) Supply Chain Resilience in the Global Financial Crisis: An Empirical Study. Supply Chain Management: An International Journal, 16, 246-259. https://doi.org/10.1108/13598541111139062

[132] Liu, Z. and Cruz, J.M. (2012) Supply Chain Networks with Corporate Financial Risks and Trade Credits under Economic Uncertainty. International Journal of Production Economics, 137, 55-67. https://doi.org/10.1016/j.ijpe.2012.01.012

[133] Raghavan, N.S. and Mishra, V.K. (2011) Short-Term Financing in a Cash-Constrained Supply Chain. International Journal of Production Economics, 134, 407-412. https://doi.org/10.1016/j.ijpe.2009.11.014

[134] Waller, M.A., Nachtmann, H. and Hunter, J. (2006) Measuring the Impact of Inaccurate Inventory Information on a Retail Outlet. The International Journal of Logistics Management, 17, 355-376. https://doi.org/10.1108/09574090610717527

[135] Zepeda, E.D., Nyaga, G.N. and Young, G.J. (2016) Supply Chain Risk Management and Hospital Inventory: Effects of System Affiliation. Journal of Operations Management, 44, 30-47. https://doi.org/10.1016/j.jom.2016.04.002

[136] Elzarka, S.M. (2013) Supply Chain Risk Management: The Lessons Learned from the Egyptian Revolution 2011. International Journal of Logistics Research and Applications, 16, 482-492. https://doi.org/10.1080/13675567.2013.846307

[137] Meena, P.L., Sarmah, S.P. and Sarkar, A. (2011) Sourcing Decisions under Risks of Catastrophic Event Disruptions. Transportation Research Part E: Logistics and Transportation Review, 47, 1058-1074. https://doi.org/10.1016/j.tre.2011.03.003

[138] Ramanathan, R. (2010) The Moderating Roles of Risk and Efficiency on the Relationship between Logistics Performance and Customer Loyalty in E-Commerce. Transportation Research Part E: Logistics and Transportation Review, 46, 950-962. https://doi.org/10.1016/j.tre.2010.02.002 
[139] Fattahi, M., Govindan, K. and Keyvanshokooh, E. (2017) Responsive and Resilient supply Chain Network Design under Operational and Disruption Risks with Delivery Lead-Time Sensitive Customers. Transportation Research Part E: Logistics and Transportation Review, 101, 176-200. https://doi.org/10.1016/j.tre.2017.02.004

[140] Li, M. and Petruzzi, N.C. (2017) Demand Uncertainty Reduction in Decentralized Supply Chains. Production and Operations Management, 26, 156-161. https://doi.org/10.1111/poms.12626

[141] Poojari, C.A., Lucas, C. and Mitra, G. (2008) Robust Solutions and Risk Measures for a Supply Chain Planning Problem under Uncertainty. Journal of the Operational Research Society, 59, 2-12. https://doi.org/10.1057/palgrave.jors.2602381

[142] Balan, S., Vrat, P. and Kumar, P. (2009) RETRACTED: Information Distortion in a Supply Chain and Its Mitigation Using Soft Computing Approach. Omega, 37, 282-299. https://doi.org/10.1016/j.omega.2007.01.004

[143] Demirkan, H. and Cheng, H.K. (2008) The Risk and Information Sharing of Application Services Supply Chain. European Journal of Operational Research, 187, 765-784. https://doi.org/10.1016/j.ejor.2006.03.060

[144] Li, G., Fan, H., Lee, P.K. and Cheng, T.C.E. (2015) Joint Supply Chain Risk Management: An Agency and Collaboration Perspective. International Journal of Production Economics, 164, 83-94. https://doi.org/10.1016/j.ijpe.2015.02.021

[145] Towill, D.R. (2005) The Impact of Business Policy on Bullwhip Induced Risk in Supply Chain Management. International Journal of Physical Distribution \& Logistics Management, 35, 555-575. https://doi.org/10.1108/09600030510623339

[146] Bandaly, D., Satir, A. and Shanker, L. (2014) Integrated Supply Chain Risk Management via Operational Methods and Financial Instruments. International Journal of Production Research, 52, 2007-2025.

https://doi.org/10.1080/00207543.2013.844376

[147] Bogataj, D. and Bogataj, M. (2007) Measuring the Supply Chain Risk and Vulnerability in Frequency Space. International Journal of Production Economics, 108, 291-301. https://doi.org/10.1016/j.ijpe.2006.12.017

[148] Gao, L. (2015) Collaborative Forecasting, Inventory Hedging and Contract Coordination in Dynamic Supply Risk Management. European Journal of Operational Research, 24, 133-145. https://doi.org/10.1016/j.ejor.2015.02.048

[149] Kern, D., Moser, R., Hartmann, E. and Moder, M. (2012) Supply Risk Management: Model Development and Empirical Analysis. International Journal of Physical Distribution \& Logistics Management, 42, 60-82.

https://doi.org/10.1108/09600031211202472

[150] Tsai, M.C., Lai, K.H., Lloyd, A.E. and Lin, H.J. (2012) The Dark Side of Logistics Outsourcing-Unraveling the Potential Risks Leading to Failed Relationships. Transportation Research Part E: Logistics and Transportation Review, 48, 178-189. https://doi.org/10.1016/j.tre.2011.07.003

[151] Kwak, D.W., Seo, Y.J. and Mason, R. (2018) Investigating the Relationship between Supply Chain Innovation, Risk Management Capabilities and Competitive Advantage in Global Supply Chains. International Journal of Operations \& Production Management, 38, 2-21. https://doi.org/10.1108/IJOPM-06-2015-0390

[152] Manuj, I., Esper, T.L. and Stank, T.P. (2014) Supply Chain Risk Management Approaches under Different Conditions of Risk. Journal of Business Logistics, 35, 241-258. https://doi.org/10.1111/jbl.12051

[153] Nooraie, S.V. and Parast, M.M. (2015) A Multi-Objective Approach to Supply 
Chain Risk Management: Integrating Visibility with Supply and Demand Risk. International Journal of Production Economics, 161, 192-200.

https://doi.org/10.1016/j.ijpe.2014.12.024

[154] Pfohl, H.C., Gallus, P. and Thomas, D. (2011) Interpretive Structural Modeling of Supply Chain Risks. International Journal of Physical Distribution \& Logistics Management, 41, 839-859. https://doi.org/10.1108/09600031111175816

[155] Revilla, E. and Saenz, M.J. (2017) The Impact of Risk Management on the Frequency of Supply Chain Disruptions: A Configurational Approach. International Journal of Operations \& Production Management, 37, 557-576. https://doi.org/10.1108/IJOPM-03-2016-0129

[156] Schoenherr, T., Tummala, V.R. and Harrison, T.P. (2008) Assessing Supply Chain Risks with the Analytic Hierarchy Process: Providing Decision Support for the Offshoring Decision by a US Manufacturing Company. Journal of Purchasing and Supply Management, 14, 100-111. https://doi.org/10.1016/j.pursup.2008.01.008

[157] Sodhi, M.S., Son, B.G. and Tang, C.S. (2012) Researchers' Perspectives on Supply Chain Risk Management. Production and Operations Management, 21, 1-13. https://doi.org/10.1111/j.1937-5956.2011.01251.x

[158] Thun, J.H. and Hoenig, D. (2011) An Empirical Analysis of Supply Chain Risk Management in the German Automotive Industry. International Journal of Production Economics, 131, 242-249. https://doi.org/10.1016/j.ijpe.2009.10.010

[159] Thun, J.H., Drüke, M. and Hoenig, D. (2011) Managing Uncertainty-An Empirical Analysis of Supply Chain Risk Management in Small and Medium-Sized Enterprises. International Journal of Production Research, 49, 5511-5525. https://doi.org/10.1080/00207543.2011.563901

[160] Vilko, J.P. and Hallikas, J.M. (2012) Risk Assessment in Multimodal Supply Chains. International Journal of Production Economics, 140, 586-595. https://doi.org/10.1016/j.ijpe.2011.09.010

[161] Wieland, A. (2013) Selecting the Right Supply Chain Based on Risks. Journal of Manufacturing Technology Management, 24, 652-668. https://doi.org/10.1108/17410381311327954

[162] Wiengarten, F., Humphreys, P., Gimenez, C. and McIvor, R. (2016) Risk, Risk Management Practices, and the Success of Supply Chain Integration. International Journal of Production Economics, 171, 361-370. https://doi.org/10.1016/j.ijpe.2015.03.020

[163] Yang, B. and Yang, Y. (2010) Postponement in Supply Chain Risk Management: A Complexity Perspective. International Journal of Production Research, 48, 1901-1912. https://doi.org/10.1080/00207540902791850 